Sains Malaysiana 50(4)(2021): 967-987

http://doi.org/10.17576/jsm-2021-5004-08

\title{
Phytochemical Profile, Antioxidant and Anti Proliferative Studies in Different Extracts of Artocarpus kemando Miq. Bark
}

(Kajian Profil Fitokimia, Antioksidan dan Anti Proliferatif dalam Ekstrak Berbeza Batang Artocarpus kemando Miq.)

\author{
Noor ShafifiYaz Mohd Yazid*, NAJihah Mohd Hashim, Hapipah Mohd Ali \& Rusea Go
}

\begin{abstract}
In this study, the stem bark of Artocarpus kemando was used to find alternative antioxidants from natural sources with fewer side effects. A. kemando was extracted successively using hexane, chloroform and methanol solvents, and evaluated for antioxidant, cytotoxic, and antiproliferative activities. The extracts were investigated for determination of their total phenolic content (TPC) and total flavonoid content (TFC). Then, the antioxidant activities were evaluated using chemical based assays such as ferric reducing antioxidant power (FRAP), total antioxidant capacity, radical scavenging of 2,2-diphenyl-1-picrylhydrazyl radical (DPPH) and 2,2'-azino-bis (3-ethylbenzothia zoline-6-sulphonic) (ABTS), $\beta$-carotene-linoleic acid (BC) assay, oxygen radical absorbance capacity (ORAC), and cell based assay. The cytotoxic study was done using four different cell lines namely human estrogen receptor positive (ER+) breast cancer cell line (MCF7), human ovarian cancer cell line (CAOV-3), human promyelocytic leukemia cell line (HL60), and normal immortalised human ovarian surface epithelial cell line (TI074), and were evaluated using microculture tetrazolium salt (MTT) before morphological change study was done on CAOV-3 cell. In this study, methanol extract displayed the most promising antioxidant activity compared to other extracts when tested with DPPH, FRAP, ABTS, TAOC, BC, ORAC, and cytoprotective assays. The remarkable activity showed by the methanol extract might be due to its high content of phenolic and flavonoid compounds at $855.5 \pm 0.01 \mathrm{GAE} \mu \mathrm{g} / \mathrm{mL}$ and $145.45 \pm 0.06 \mathrm{QAE} \mu \mathrm{g} / \mathrm{mL}$, respectively. Nevertheless, the chloroform extract displayed better scavenging activity compared to other extracts with $I_{50}$ value of $618 \pm 0.04 \mu \mathrm{g} / \mathrm{mL}$ in DPPH assay. Each extract was analysed using Gas Chromatography Mass Spectrophotometry and the chemical constituents obtained were then analysed. In the cytoprotective activity, the methanol extract showed a comparable cytoprotection with ascorbic acid against the free radicals at the lowest effective concentration $\left(E C_{50}\right)$ value of $21.48 \mu \mathrm{g} / \mathrm{mL}$. However, in the cytotoxicity study, only chloroform extract displayed significant toxicity against the cancer cells with $I C_{50}$ value of $27.9 \pm 0.03,24.1 \pm 0.02$ and $9.0 \pm 0.04 \mu \mathrm{g} / \mathrm{mL}$ after treatment at 24,48 , and $72 \mathrm{~h}$, respectively. The chloroform extract of A. kemando was found capable of inducing apoptosis as shown with cell membrane blebbing, chromatin condensation and formation of apoptotic bodies. The results obtained from the study showed that A. kemando bark could be a potential antioxidant and antitumor agents particularly on human ovarian cancer cells.
\end{abstract}

ABSTRACT

Keywords: Antioxidant; antitumour; Artocapus kemando; cytoprotective; Malaysia

\section{ABSTRAK}

Dalam kajian ini, kulit batang Artocarpus kemando digunakan untuk mencari antioksidan alternatif daripada sumber semula jadi dengan kesan sampingan yang kurang. Kulit batang pokok A. kemando diekstrak secara berturutan menggunakan pelarut heksana, kloroform dan metanol serta dinilai untuk aktiviti antioksidan, sitotoksik dan antiproliferatif. Kesemua ekstrak telah dikaji untuk penentuan kandungan jumlah fenolik (TPC) dan jumlah flavonoid (TFC). Kemudian, aktiviti antioksidan telah dinilai melalui ujian berasaskan kimia seperti keupayaan antioksida mengurangkan ferum (FRAP), jumlah kapasiti antioksidan (TAOC), asai pengurangan radikal bebas menggunakan 2,2-difenil-1-pikrilhidrazil (DPPH) dan 2,2'-azino-bis (3-etilbenzotiazolin-6-sulfonik) (ABTS), asai asid $\beta$-karotenlinoleik (BC), kapasiti penyerapan oksigen radikal (ORAC), dan ujian berasaskan sel. Kajian sitotoksik dilakukan menggunakan empat titisan sel yang berbeza iaitu titisan sel kanser payudara positif reseptor estrogen (ER +) (MCF7), titisan sel kanser ovari manusia (CAOV-3), titisan sel leukemia promoelositik manusia (HL60) dan titisan sel normal permukaan epitelial ovari manusia (TI074), serta dinilai menggunakan garam mikro tetrazolium (MTT) sebelum kajian perubahan morfologi dilakukan terhadap sel CAOV-3. Dalam kajian ini, ekstrak metanol menunjukkan aktiviti antioksidan 
yang paling baik berbanding ekstrak lain apabila diuji dengan DPPH, FRAP, ABTS, TAOC, BC, ORAC dan asai sitoprotektif. Aktiviti luar biasa yang ditunjukkan oleh ekstrak metanol mungkin disebabkan oleh kandungan sebatian fenolik dan flavonoid yang tinggi iaitu masing-masing $855.5 \pm 0.01 \mathrm{GAE} \mu \mathrm{g} / \mathrm{mL}$ dan $145.45 \pm 0.06 \mathrm{QAE} \mu \mathrm{g} / \mathrm{mL}$. Walau bagaimanapun, ekstrak kloroform menunjukkan aktiviti pengurangan radikal yang lebih baik berbanding ekstrak lain dengan nilai $I_{50} 618 \pm 0.04 \mu \mathrm{g} / \mathrm{mL}$ dalam asai DPPH. Setiap ekstrak telah dianalisis menggunakan Spektrofotometri Jisim Kromatografi Gas dan komponen kimia yang diperoleh kemudiannya dianalisis. Bagi aktiviti sitoprotektif, ekstrak metanol menunjukkan keupayaan sitoperlindung setanding dengan aktiviti asid askorbik terhadap radikal bebas pada nilai kepekatan berkesan yang paling rendah $\left(E C_{50}\right)$ iaitu $21.48 \mu \mathrm{g} / \mathrm{mL}$. Walau bagaimanapun, dalam kajian sitotoksisiti, hanya ekstrak kloroform yang menunjukkan ketoksikan signifikan terhadap sel kanser dengan nilai IC ${ }_{50}$ masing-masing sebanyak 27.9 $\pm 0.03,24.1 \pm 0.02$ dan $9.0 \pm 0.04 \mu \mathrm{g} / \mathrm{mL}$ selepas rawatan pada 24, 48 dan 72 jam. Ekstrak chloroform $\mathrm{A}$. kemando didapati berupaya mengaruh apoptosis sebagaimana ditunjukkan dengan penunasan membran sel, pengecutan kromatin dan pembentukan jasad apoptosis. Hasil yang diperoleh daripada kajian menunjukkan bahawa batang pokok A. kemando berpotensi sebagai agen antioksidan dan antitumor terutama ke atas sel kanser ovari manusia.

Kata kunci: Antioksidan; antitumor; Artocarpus kemando; Malaysia; sitopelindung

\section{INTRODUCTION}

Antioxidant is a substance that will significantly delay or prevent oxidation even at low concentration. In certain conditions, oxidation may produce free radicals that can cause oxidative stress through production of reactive oxygen species (ROS). ROS has variable chemical activities capable of penetrating and crossing the plasma membrane. The ability to interact at cellular level makes these radical components capable of damaging cells which can lead to degenerative diseases such as cancer, ulcer, and atherosclerosis (Nair et al. 2012). Thus, antioxidants play important roles in preventing oxidative damage by neutralising free radicals hence preventing chronic diseases by scavenging free radicals and modulating pathways in cell signaling (Matés et al. 1999) which make them great candidates in preventing degenerative diseases such as cancer. Antioxidants could modulate cell signaling pathway by forestalling cancer cell growth which include the regulation of normal cell cycle preservation, inhibiting proliferation by inducing apoptosis, preventing angiogenesis, tumour invasion and suppressing inflammation (Valko et al. 2007).

However, synthetic antioxidants such as butylated hydroxytoluene (BHT) have been regulated as they have been suspected to cause liver damage and carcinogenesis (Altuntaş \& Değer 2017; Witschi et al. 1989). This has prompted the efforts to find alternative antioxidants from natural sources with fewer side effects. As part of our continuing search for natural antioxidants in Artocarpus species (Hashim et al. 2012), A. kemando Miq. was selected due to its excellent performance in the previous study.

A. kemando belongs to the family Moraceae and is found throughout Southeast Asia. In ethnopharmacological studies, some parts of the plant such as its bark, leaves, seeds, fruits and roots have been used to treat diarrhoea, fever, liver cirrhosis, hypertension, diabetes, ulcer, malaria, inflammation, wounds, and even tapeworm infections (Khan et al. 2003). According to Jamil et al. (2008), Artocarpus spp. contain interesting compounds such as phenolics, flavonoids, chalcones, stilbenes, and xanthones, which are all potential natural antioxidants.

Previous phytochemical studies on Artocarpus species had showed that this genus is rich with interesting phenolic compounds. According to Ee et al. (2011) and Wei et al. (2005), phenolic constituents in this genus contribute to various activities such as antioxidants, antiinflammatory and cytotoxic effects. Phenolics are potent antioxidants which can inhibit lipid peroxidation by scavenging free radicals such as peroxyl radicals (ROO•) and hydroxyl radicals (HO•) (Beta et al. 2007). The plant extracts of Artocarpus spp. such as A. communis, $A$. bracteate and $A$. reticulatus also contained several useful bioactive compounds such as kanzonol $\mathrm{C}$ (chalcone), artocarpanone (flavanone), catechin (flavan-3-ol), morusinc (3-prenylflavone) and oxyresveratrol (stilbene) (Jagtap \& Bapat 2010).

A few compounds were determined in Seo et al. (2003) as shown in Figure 1. The compounds are artonins E (3), artonins O (4), artobiloxanthone (5), cycloartobiloxanthone (7) while Hashim et al. (2011) reported that there were four main isolated compounds in this species known as cycloartobiloxanthone (7), dihydroartoindonesianin $\mathrm{C}(8)$, aurantiamide benzoate (6) and 6,7-dimethoxycoumarin (9). In other findings, this species also contained artomandin (1), artonol B (2) and artoindonesianin C (10) (Teo et al. 2012).

Nevertheless, there was minimal evidence concerning the antioxidant activities of A. kemando. 
Previous studies generally focused on the isolation of various compounds found in this species, and only a few have discussed their biological activities. Hence, there is a necessity to explore the antioxidant properties of the species and their effects on the growth of cancer cells, as the antioxidant properties of these fascinating plants and their oxidation mechanisms were varied (Shahidi \& Ho 2007). Thus, the purpose of the present study was to explore the phenolic and flavonoid contents in the bark of A. kemando and evaluate their antioxidant and anti-tumour activities using different in vitro models.<smiles>CC1(C)C=Cc2c(cc(O)c3c(=O)c4c(oc23)-c2cc(O)c(O)c3c2C(C4)C(C)(C)O3)O1</smiles><smiles>CC(=O)c1c2c(cc3c(=O)c4c(O)cc5c(c4oc13)C=CC(C)(C)O5)C(=O)OC2(C)C</smiles>

2<smiles>CC(C)=CCc1c(-c2cc(O)c(O)cc2O)oc2c3c(cc(O)c2c1=O)OC(C)(C)C=C3</smiles><smiles>C=C(C)C1Cc2c(oc3cc(O)c(CC=C(C)C)c(O)c3c2=O)C2=C1C(=O)C(O)=C(CC=C(C)C)C2=O</smiles><smiles>C=C(C)C1Cc2c(oc3c4c(cc(O)c3c2=O)OC(C)(C)C=C4)-c2c(O)cc(O)c(O)c21</smiles> 
<smiles>[Mg]</smiles>

6<smiles>CC1(C)C=Cc2c(cc(O)c3c(=O)c4c(oc23)-c2c(O)cc(O)c3c2C4CC3(C)C)O1</smiles>

7<smiles>COc1cc2ccc(=O)oc2cc1OC</smiles>

9<smiles>CC(C)c1cc2c(=O)c3c(O)cc4c(c3oc2c2c1C(C)(O)CC2=O)C=CC(C)(C)O4</smiles>

8<smiles>C=C(C)c1cc2c(=O)c3c(O)cc4c(c3oc2c2c1C(O)(C(=O)OC)CC2=O)C=CC(C)(C)O4</smiles>

10

FIGURE 1. Structure of compounds discovered in Artocarpus kemando from previous studies such as artomandin (1), artonol B (2), artonins E (3), artonins O (4), artobiloxanthone (5), aurantiamide benzoate (6), cycloartobiloxanthone (7), dihydroartoindonesianin C (8), 6, 7-dimethoxycoumarin (9) and artoindonesianin C (10)

\section{MATERIALS AND METHODS}

\section{PLANT SAMPLE}

The fresh stem bark of $A$. kemando was obtained from the Department of Biology, Faculty of Science, Universiti Putra Malaysia, Selangor, Malaysia (2॰59'34.19” N $\left.101^{\circ} 42^{\prime} 16.79^{\prime \prime} \mathrm{E}\right)$. The sample was shade-dried at room temperature for a week and crushed using an electric mixer (Retsch Cutter Mill). The sample was then deposited with voucher specimen number S93753 and kept in the Herbarium, Department of Biology, Faculty of Science, Universiti Putra Malaysia, Selangor, Malaysia.
PREPARATION OF A. kemando EXTRACTS

The air-dried stem bark was ground into fine powder and extracted three times at room temperature for three consecutive days each time. The organic solvents used were hexane followed by chloroform $\left(\mathrm{CHCl}_{3}\right)$ and finally methanol (MeOH) with 1:1.5 ratio as reported in Azwanida (2015) with slight modifications. The extracts were filtered and then concentrated using rotary evaporator under reduced pressure. Then, the crude extract was dissolved in dimethyl sulfoxide (DMSO) which was then used for chemical and biological assays. 
DETERMINATION OF TOTAL FLAVONOID CONTENT

The total flavonoid content (TFC) was performed following Chang et al. (2002), a colorimetric technique with slight modification. The extract and standard control were diluted in DMSO $(10 \mu \mathrm{L})$ and mixed with $60 \mu \mathrm{L}$ methanol, $10 \mu \mathrm{L}$ of aluminium chloride $(10 \%$ concentration) and distilled water $(120 \mu \mathrm{L})$ followed by $10 \mu \mathrm{L}$ of potassium acetate $(1 \mathrm{M})$ and incubated for $30 \mathrm{~min}$. The absorbance was measured at $415 \mathrm{~nm}$ (Tecan, Infinite M200 Pro). Quercetin was used as a standard control for the calibration curve from 31.25 to $1000 \mu \mathrm{g} / \mathrm{mL}$.

\section{DETERMINATION OF TOTAL PHENOLIC CONTENT}

The assay was performed following Oki et al. (2002) with a slight modification. A total of $20 \mu \mathrm{L}$ of extract (1 $\mathrm{mg} / \mathrm{mL}$ ) was mixed into $50 \mu \mathrm{L}$ of $10 \%$ Folin-Ciocalteu (FC) reagent. The sample was incubated for $3 \mathrm{~min}$ at room temperature before addition of $100 \mu \mathrm{L}$ of $10 \%$ sodium carbonate $\left(\mathrm{Na}_{2} \mathrm{CO}_{3}\right)$ solution and incubated in the dark for $1 \mathrm{~h}$. The absorbance was measured at $750 \mathrm{~nm}$ (Tecan, Infinite M200 Pro). Gallic acid (2 mg) was dissolved in 10 $\mathrm{mL}$ of methanol and diluted into a series of concentrations $(0,200,400,600,800,1000 \mu \mathrm{g} / \mathrm{mL})$, and then used as a standard while sample carrier solution was used as a blank with equivalent parameter as in (1):

$$
\mathrm{C}=\mathrm{c}(\mathrm{V} / \mathrm{m})
$$

where $\mathrm{C}$ is the total phenolic content $\mu \mathrm{g}$ GAE/g dry extract; $\mathrm{c}$ is the concentration of gallic acid obtained from calibration curve in $\mathrm{mg} / \mathrm{mL}$; $\mathrm{V}$ is the volume of extract in $\mathrm{mL}$; and $\mathrm{m}$ is the mass of extract in gram.

\section{A. kemando PROFILING CONDITIONS}

Gas Chromatography Mass Spectrometry (GC-MS) analysis was carried out using QP2010 Plus Shimadzu GCMS system linked with the NIST 08S library at Faculty of Science, Universiti Putra Malaysia. The sample $(1 \mathrm{mg} / \mathrm{mL})$ was used in liquid injection method with a fused-silica capillary column SGE BPX5 $(30 \mathrm{~m} \times 0.25 \mathrm{~mm}$ 1.D $\times 0.25 \mu \mathrm{m}$ film thickness). The oven temperatures were set as follows: $50^{\circ} \mathrm{C}$ held for $3 \mathrm{~min}$ and then ramped at $10^{\circ} \mathrm{C} / \mathrm{min}$ to $220-300{ }^{\circ} \mathrm{C}$ and held for 15 to $20 \mathrm{~min}$. A splitless injector was used in the split less mode with column ratio equal to $30.5 \mathrm{~mL} / \mathrm{min}$. Helium was chosen as the carrier gas with continuous flow of $3.0 \mathrm{~mL} / \mathrm{min}$. The injector temperature was kept between $220{ }^{\circ} \mathrm{C}$ and $240{ }^{\circ} \mathrm{C}$, while source and transfer line temperatures were 220 and $250{ }^{\circ} \mathrm{C}$, respectively. In mass spectrometry detection, the ion energy used for the electron ionization (EI) was $70 \mathrm{eV}$. in vitro EVALUATION OF ANTIOXIDANT ACTIVITY

All antioxidant experiments and analyses were executed in triplicates and the results were reported as means plus standard deviations (SD).

\section{FERRIC REDUCING ANTIOXIDANT POWER (FRAP) ASSAY}

The reducing power of the crude extracts using the FRAP assay was conducted as described by Benzie and Strain (1996). The $10 \mu \mathrm{L}$ extract $(1 \mathrm{mg} / \mathrm{mL})$ was mixed with $300 \mu \mathrm{L}$ of FRAP reagent $(300 \mathrm{mM}$ acetate buffer $\mathrm{pH} 3.6$, $10 \mathrm{mM}$ TPTZ in $\left.40 \mathrm{mM} \mathrm{HCl}, 20 \mathrm{mM} \mathrm{FeCl}_{3} \cdot 6 \mathrm{H}_{2} \mathrm{O}\right)$. Then, the absorbance was measured at $593 \mathrm{~nm}$ (Tecan, Infinite M200 Pro) from 0 to $4 \mathrm{~min}$. An aqueous solution of $\mathrm{FeSO}_{4} \cdot 7 \mathrm{H}_{2} \mathrm{O}$ was used to construct a calibration curve in the range between 200 and $1000 \mu \mathrm{M}$. The antioxidant power value was expressed as $\mu \mathrm{mol}$ of ferrous sulphate per gramme of dried sample $(\mu \mathrm{mol} / \mathrm{g})$.

\section{TOTAL ANTIOXIDANT CAPACITY (TAOC)}

The total antioxidant capacities of the A. kemando extracts were analysed according to the technique described by Sun et al. (2011). The extract $(0.3 \mathrm{~mL})$ was mixed with $3 \mathrm{~mL}$ of the reagent solution $(28 \mathrm{mM}$ sodium phosphate, $4 \mathrm{mM}$ ammonium molybdate, $0.6 \mathrm{M}$ sulphuric acid). Then, the mixtures were incubated at 95 ${ }^{\circ} \mathrm{C}$ for $90 \mathrm{~min}$. After it had cooled to room temperature, $300 \mu \mathrm{L}$ of each mixture was loaded into a 96-well micro plate and analysed at $695 \mathrm{~nm}$. The total antioxidant activity was expressed as ascorbic acid equivalents (Govindarajan et al. 2003). The blank contained $3 \mathrm{~mL}$ of reagent solution and $0.3 \mathrm{~mL}$ distilled water with no sample present.

\section{RADICAL-SCAVENGING ACTIVITY USING 2,2-DIPHENYL-} 1-PICRYLHYDRAZYL (DPPH)

The DPPH assay was carried out as performed in Hashim et al. (2012). A total of $100 \mu \mathrm{L}$ of extract $(1 \mathrm{mg} / \mathrm{mL})$ was added to $100 \mu \mathrm{L}$ of DMSO as diluent in the first row of 96 well-microplates. A series of concentration ranging from 500 to $7.8 \mu \mathrm{g} / \mathrm{mL}$ were prepared in two-fold dilution. Then, $10 \mu \mathrm{L}$ of DPPH $(2.5 \mathrm{mg} / \mathrm{mL}$ in DMSO $)$ was added to each well. After 30 min incubation in the dark, the absorbance was measured at $517 \mathrm{~nm}$ (Tecan, Infinite M200 Pro). Ascorbic acid was used as positive control. The percentage of inhibition was calculated using (2).

$$
\% \text { inhibition }=\left[\left(A_{B}-A_{E}\right) / A_{B}\right] \times 100
$$


where $A_{B}$ is the absorbance of the blank sample; and $A_{E}$ is the absorbance of the plant extract.

The $\mathrm{IC}_{50}$ value was determined as the concentration of each sample required to scavenge $50 \%$ of free radical molecules.

\section{RADICAL SCAVENGING ACTIVITY USING 2,2'-AZINO-BIS} (3-ETHYLBENZOTHIAZOLINE-6-SULFONIC ACID) (ABTS)

Free radical scavenging assays were performed using the ABTS method described by Dudonné et al. (2009). ABTS was diluted to $7 \mathrm{mM}$ using deionised water. Then, potassium persulphate solution $(2.45 \mathrm{mM})$ was added to generate $\mathrm{ABTS}$ radical cations $\left(\mathrm{ABTS}^{+\bullet}\right)$. The mixture was incubated in the dark for 12 to $16 \mathrm{~h}$ at room temperature. The $\mathrm{ABTS}^{+} \bullet$ solution was diluted in deionised water until its absorbance reading was $0.7( \pm 0.02)$ at $743 \mathrm{~nm}$. Using a slightly modified method, $10 \mu \mathrm{L}$ of extract or DMSO (as blank) was added to the 96-well microplate followed by $300 \mu \mathrm{L} \mathrm{ABTS}^{+}$. The plate was kept warm for $10 \mathrm{~min}$ at $30{ }^{\circ} \mathrm{C}$ and the absorbance was recorded at $734 \mathrm{~nm}$. All determinations were performed in triplicates. The percentage inhibition was calculated using (3).

$$
\% \text { inhibition }=\left[\left(A_{B}-A_{E}\right) / A_{B}\right] \times 100
$$

where $A_{B}$ is the absorbance of the blank sample; and $A_{E}$ is the absorbance of the plant extract.

The $\mathrm{IC}_{50}$ value was determined as the concentration of each sample required to scavenge $50 \%$ of free radical molecules.

\section{B-CAROTENE-LINOLEIC ACID SYSTEM}

The $\beta$-carotene $(\mathrm{BC})$ with linoleic acid system was used done as described by Zubia et al. (2009), with minor modifications. Beta-carotene (BC, $1 \mathrm{mg}$ ) was dissolved in $1 \mathrm{~mL}$ chloroform before $210 \mu \mathrm{L}$ of the solution added into a round bottomed flask containing $5 \mu \mathrm{L}$ linoleic acid and $42 \mu \mathrm{L}$ Tween 40 . Chloroform was removed using a rotary evaporator at $40{ }^{\circ} \mathrm{C}$. Distilled water $(10 \mathrm{~mL})$ was added to the semi-solid residue and an emulsion was formed by vigorous shaking.

The BC emulsion $(200 \mu \mathrm{L})$ was then loaded onto 96-well microplate together with $50 \mu \mathrm{L}$ extract $(1 \mathrm{mg} /$ $\mathrm{mL}$ ) which had been diluted in methanol in each well. In this experiment, butylated hydroxytoluene (BHT) and 6-hydroxy-2,5,7,8-tetramethylchroman-2-carboxylic acid (Trolox) were used as positive controls while methanol was used as a blank. Absorbance was read at $470 \mathrm{~nm}$ at the 0 and $120 \mathrm{~min}$ of incubation at $50{ }^{\circ} \mathrm{C}$ in the dark. The measurements were done in triplicates. The antioxidant activity (AA) was measured according to (4):

$$
\mathrm{AA} \%=1-\left[\left(\mathrm{A}_{\mathrm{t}=0}-\mathrm{A}_{\mathrm{t}=120}\right) /\left(\mathrm{A}_{\mathrm{c}=0}-\mathrm{A}_{\mathrm{c}=120}\right)\right] \times 100
$$

where $\mathrm{A}_{t=0}$ is the absorbance of the sample at $0 \mathrm{~min} ; \mathrm{A}_{\mathrm{t}=120}$ is the absorbance at $120 \mathrm{~min} ; \mathrm{A}_{\mathrm{c}=0}$ is the absorbance of the blank at $0 \mathrm{~min}$; and $\mathrm{A}_{\mathrm{c}=120}$ is the absorbance at $120 \mathrm{~min}$.

\section{OXYGEN RADICAL ABSORBANCE CAPACITY (ORAC)} ASSAY

The ORAC method was adapted from Dávalos et al. (2004). The reaction was performed in phosphate buffer $(75 \mathrm{mM})$ at $\mathrm{pH} 7.4$. The extract $(20 \mu \mathrm{L})$ and $120 \mu \mathrm{L}$ of fluorescein mixture (final concentration $70 \mathrm{nM}$ ) were added into 96-well microplate. The mixture was pre-incubated for $15 \mathrm{~min}$ at $37^{\circ} \mathrm{C}$. Then, $60 \mu \mathrm{L}$ of AAPH solution (final concentration of $12 \mathrm{mM}$ ) was added to each well. The absorbance was read every minute for $80 \mathrm{~min}$. Trolox was used at seven different concentrations (final concentrations ranging from 5 to $100 \mu \mathrm{M}$ ) to create a calibration curve, and phosphate buffer was used as a blank. The antioxidant activity was estimated by measuring the area under the fluorescence decay curve (AUC) of the samples, blank and standards. From the normalised curves, the AUC was calculated using (5).

$$
\mathrm{AUC}=1+\sum_{i=1}^{i=80} f i / f 0
$$

where $f_{0}$ is the initial fluorescence reading at time zero; and $f_{i}$ is the fluorescence reading at time $i$.

The net AUC result for each sample was calculated by subtracting the AUC corresponding to the blank, and a standard curve (net AUC of Trolox vs. Trolox concentration) created. The ORAC-FL values were calculated via linear regression using an equation derived from the standard curve. The values were stated in $\mu \mathrm{mol}$ per kilogramme of Trolox equivalents. All samples were assayed in triplicates and the data were presented as mean \pm SD.

\section{ANTIOXIDANT CYTOPROTECTIVE ASSAY}

This assay was performed using Tomosaka et al. (2008) method with a slight modification. At a density of $1 \times$ $10^{4}$ cells per well, T1074 (normal immortalized human ovarian surface epithelial) cells were seeded in 96-well plates. The cells were treated with $A$. kemando extracts and positive controls (ascorbic acid and quercetin) according to their anti-radical activity $\left(\mathrm{IC}_{50}\right.$ value of DPPH 
assay) for $24 \mathrm{~h}$. Then, cumene hydroperoxide $\left(\mathrm{C}_{9} \mathrm{H}_{12} \mathrm{O}_{2}\right.$, $620 \mu \mathrm{M}$, final concentration) was added as a free radical inducer and the plates were incubated in $\mathrm{CO}_{2}$ incubator $\left(37^{\circ} \mathrm{C}, 1 \mathrm{~h}\right)$. The protective activity of the samples was then examined using Hoechst 33342 and AOPI dyes.

\section{CELL COUNT ANALYSIS USING HOECHST 33342 STAINING AND CELL REPORTER}

To measure cell morphology, the nuclei of the living cells were stained with Hoechst 33342 dye to distinguish them for counting. The media was completely removed from the well and each well was washed with $100 \mu \mathrm{L}$ of PBS. The Hoechst 33342 dye was diluted down to $10 \mu \mathrm{g} / \mathrm{mL}$ in PBS before $20 \mu \mathrm{L}$ of it was added into each well. After $20 \mathrm{~min}$ of incubation, $100 \mu \mathrm{L}$ of PBS was added to each well before the cells were viewed under CellReporter ${ }^{\mathrm{TM}}$ System from Molecular Devices.

\section{MORPHOLOGICAL ANALYSIS USING HOECHST 33342 STAINING AND FLUORESCENCE MICROSCOPE}

The cells $\left(1 \times 10^{6}\right.$ cells $\left./ \mathrm{mL}\right)$ were seeded with active extracts at $\mathrm{EC}_{50}$ concentration and cumene hydroperoxide in the $25 \mathrm{~mL}$ flasks for incubation $\left(37^{\circ} \mathrm{C}, 1 \mathrm{~h}\right)$. Cells were then collected by centrifugation at $1600 \mathrm{~g}$ for $10 \mathrm{~min}$. Then, the cells were washed with PBS before the addition of Hoechst 33342 dye. The Hoechst 33342 dye was diluted into $10 \mu \mathrm{g} / \mathrm{mL}$ in PBS and subsequently added (60 $\mu \mathrm{L}$ ) into the centrifuge tube. After $20 \mathrm{~min}$ of incubation, a total of $300 \mu \mathrm{L}$ of PBS was added to the tube before the cells were mounted on the slide. The morphological changes of the cells were observed under UV-fluorescence microscope.

\section{MORPHOLOGICAL ANALYSIS USING AO/PI STAINING}

AO/PI staining was done to determine the cell morphological changes. The cells $\left(1 \times 10^{6}\right.$ cells $\left./ \mathrm{mL}\right)$ seeded with active extracts at $\mathrm{EC}_{50}$ concentration and cumene hydroperoxide in the $25 \mathrm{~mL}$ flasks for incubation $\left(37^{\circ} \mathrm{C}, 1 \mathrm{~h}\right)$. The treated cell suspensions were harvested and centrifuged at $1600 \mathrm{~g}$ for $10 \mathrm{~min}$. The harvested cells were washed before mixing with an equal volume of staining solution (1:1) containing acridine orange (10 $\mu \mathrm{g} / \mathrm{mL})$ and propidium iodide $(10 \mu \mathrm{g} / \mathrm{mL})$ and observed under UV-fluorescence microscope within $30 \mathrm{~min}$. The morphology of viable (green intact cells), apoptotic (green shrinking cells with condensed or fragmented nuclei) and necrotic (red cells) cells were observed under UVfluorescence microscope.

\section{CYTOTOXIC ANALYSIS BY THE MTT ASSAY}

This method was performed in 96-flat bottom microwell plates using microculture tetrazolium salt (MTT) as in Mosmann (1983). The stock solution of the crude extract was prepared at the concentration of $10 \mathrm{mg} / \mathrm{mL}$ in DMSO. Each well was filled with $100 \mu \mathrm{L}$ of varying sample concentrations $(30,15,7.5,3.75,1.87,0.93$, and $0.46 \mu \mathrm{g} / \mathrm{mL})$. Pre-completed growth medium was added $(100 \mu \mathrm{L})$ to each well of exponentially growing cell suspension of $5 \times 10^{5}$ cells $/ \mathrm{mL}$. Untreated cells were used as control for each sample. The assays were performed in triplicates and the treated cells were incubated for $72 \mathrm{~h}$ $\left(37^{\circ} \mathrm{C}, 5 \% \mathrm{CO}_{2}\right.$. In this method, the viability of cells was determined by measuring the formation of blue formazan crystals after the addition of $20 \mu \mathrm{L}$ freshly prepared MTT solution ( $5 \mathrm{mg}$ in $1 \mathrm{~mL}$ PBS) followed by $4 \mathrm{~h}$ incubation at $37{ }^{\circ} \mathrm{C}$. Subsequently, $170 \mu \mathrm{L}$ of the remaining media was removed and $100 \mu \mathrm{L}$ of DMSO was added to each well and mixed thoroughly to dissolve the blue crystal formazan. The plate was incubated for $30 \mathrm{~min}$ before absorbance (OD) was read at at $570 \mathrm{~nm}$ using a microplate reader (Tecan, Infinite M200 Pro). Paclitaxel was used as a positive control. The percentage of cell viability was determined using (6).

$$
\% \text { Cell viability }=\frac{\text { OD sample } \times 100}{\text { OD control }}
$$

A graph was plotted for the percentage of cell viability against sample concentration and the cytotoxicity index used was $\mathrm{IC}_{50}$, the concentration that yielded $50 \%$ inhibition of the cell compared to untreated control.

\section{MORPHOLOGICAL AND QUANTITATIVE ANALYSIS OF TREATED CAOV-3 CELL USING FLORESCENCE MICROSCOPY}

The AO/PI staining was done to measure cell death through plasma membrane integrity and morphological changes. The cells $\left(1 \times 10^{6}\right.$ cells $\left./ \mathrm{mL}\right)$ were seeded with chloroform crude extract at $\mathrm{EC}_{50}$ concentration (Table 7) in the $25 \mathrm{~mL}$ flasks for incubation at 24, 48 and 72 $\mathrm{h}$ at $37^{\circ} \mathrm{C}$. The treated cell suspensions were harvested and centrifuged at $1600 \mathrm{~g}$ for $10 \mathrm{~min}$. The harvested cells were washed before mixing with equal volume of staining solution (1:1) containing acridine orange (10 $\mu \mathrm{g}$ ) $\mathrm{mL})$ and propidium iodide $(10 \mu \mathrm{g} / \mathrm{mL})$ and was observed under UV-fluorescence microscope within $30 \mathrm{~min}$. The viable (green intact cells), apoptotic (green shrinking cells with condensed or fragmented nuclei) and necrotic (red cells) cells were also observed under UV-fluorescence microscope. 
STATISTICAL ANALYSIS

All tests were performed in triplicates and the results were presented as mean \pm standard deviation (SD). The values were compared to the positive controls, in which it may be considered as significant if $P<0.05$. Statistical analysis was performed using SPSS-16.0 and GraphPad prism 6.0.

\section{RESULTS}

\section{YIELD OF A. kemando CRUDE EXTRACTS}

The fine ground stem bark of $A$. kemando was extracted successively using cold maceration for $72 \mathrm{~h}$ in organic solvents (hexane, chloroform, and methanol). Evaporation of excess solvent using a rotary evaporator yielded hexane, chloroform and methanol extracts as summarised in Table 1.

TABLE 1. Yield of $A$. kemando crude extract

\begin{tabular}{lccc}
\hline $\begin{array}{c}\text { Crude } \\
\text { extracts }\end{array}$ & $\begin{array}{c}\text { Air dried weight } \\
(\mathrm{g})\end{array}$ & $\begin{array}{c}\text { Weight of crude extract } \\
(\mathrm{g})\end{array}$ & $\begin{array}{c}\text { Percentage of yield } \\
(\%)\end{array}$ \\
\hline Hexane & & 16.00 & 2.46 \\
Chloroform & 650 & 15.23 & 2.34 \\
Methanol & & 34.69 & 5.34 \\
\hline
\end{tabular}

QUANTITATIVE MEASUREMENT OF TOTAL PHENOLIC AND TOTAL FLAVONOID CONTENTS IN $A$. kemando EXTRACTS

In total phenolic content measurements, the results were expressed as gallic acid equivalents (Table 2). The methanol crude extract exhibited the highest total phenolic content followed by the chloroform and hexane extracts. By contrast, the methanol extract exhibited the highest flavonoid content followed by the hexane extract and the chloroform extract.

TABLE 2. The total phenolic and flavonoid content of $A$. kemando crude extracts

\begin{tabular}{lcc}
\hline \multicolumn{1}{c}{ Crude extracts } & Total phenolic content $(\mathrm{GAE} \mu \mathrm{g} / \mathrm{g})$ & Total flavonoid content $(\mathrm{QE} \mu \mathrm{g} / \mathrm{g})$ \\
\hline Hexane & $70.36 \pm 0.02$ & $5.28 \pm 0.02$ \\
Chloroform & $520.78 \pm 0.03$ & $45.45 \pm 0.01$ \\
Methanol & $855.50 \pm 0.01$ & $145.45 \pm 0.06$ \\
\hline
\end{tabular}

All values represented means $\pm \mathrm{SD}$ of three replicates

\section{DETERMINATION OF CHEMICAL CONSTITUENTS OF $A$. kemando EXTRACTS BY GAS CHROMATOGRAPHY-MASS SPECTROMETRY (GC-MS) ANALYSIS}

The chemical profile of each extract was analysed by comparing the retention time, peak area, and molecular weight with the similarity index in NIST 08S library. The
GCMS results were presented in Table 3 with more than 90 similarity indices. The first three compounds detected were 2-hexanol (in hexane extract), 1,5-heptadiene,3,3,3trimethyl (chloroform extract) and phosponic acid (methanol extract). Oxacycloheptadec-8-en-2-one and 9,19-cyclolanostan-3-ol were successfully identified in both hexane and chloroform extracts. 
In accordance to GCMS results, there was no similarity of compounds present in methanol and chloroform extracts. However, it could be concluded that both extracts consisted of the same chemical group such as benzoic acid. Based on the GCMS analysis, the chemical components present in hexane extract were alcohol, ketone, acid and ester groups. Eight compounds were successfully identified with 9,19-cyclolanostan- 3-ol, 24-methylene detected as the major compound. In the chloroform extract, 13 compounds were detected consisting of acid, ester, ketone, aldehyde, and alcohol groups while 9,19-cyclolanoston-3-ol and benzoic acid were the major compounds present in the extract. Meanwhile, there were 14 compounds detected in the methanol crude extract which consisted of acid, ketone, aldehyde and alcohol groups. Phosphonic acid was the major compound identified in this crude extract.

TABLE 3. The chemical composition in the A. kemando extracts analysed by GC-MS

\begin{tabular}{|c|c|c|c|c|}
\hline Plant extracts & Compounds & Retention time (min) & Area peak $(\%)$ & Compound groups \\
\hline \multirow{8}{*}{ Hexane } & 2-Hexanol & 4.495 & 0.04 & Alcohol \\
\hline & Oxacyclotetradecan-2-one & 20.685 & 0.07 & Ketone \\
\hline & 7-Hexadecenoic & 22.716 & 0.31 & Acid \\
\hline & cis-Vaccenic acid & 25.998 & 0.02 & Acid \\
\hline & 9,19-Cyclolanostan-3-ol, 24-methylene-, (3.beta.)- & 35.448 & 2.87 & Alkene \\
\hline & Lupenyl acetate & 36.222 & 19.82 & Ester \\
\hline & 9,19[-Cyclolanostan-3-ol, 24-methylene-, (3.beta.) & 36.942 & 2.00 & Alkene \\
\hline & 9,19-Cyclolanostan-3-ol, 24-methylene-, (3.beta) & 37.346 & 53.72 & Alkene \\
\hline \multirow{13}{*}{ Chloroform } & 1,5-Heptadiene,3,3,3-trimethyl & 6.610 & 0.37 & Alkene \\
\hline & Undecane & 7.778 & 0.56 & Alkane \\
\hline & 1,3-Butadiene, 1,1,2,3,4,4-hexachloro & 9.098 & 0.96 & Alkene \\
\hline & Cyclohexasiloxane, dodecamethyl & 9.912 & 1.18 & Alkane \\
\hline & $\begin{array}{l}\text { Benzoic acid, 2, 4- dihydorxy-3,6- dimethyl, } \\
\text { methyl ester }\end{array}$ & 14.755 & 7.10 & Acid \\
\hline & Hexadecanoic acid, methyl ester & 16.999 & 0.61 & Acid \\
\hline & Cyclopentadecanone, 2-hydroxy & 17.230 & 0.17 & Ketone \\
\hline & Oxacycloheptadec-8-en-2-one & 19.256 & 0.41 & Ketone \\
\hline & Cyclononasiloxane, octadecamethyl & 19.576 & 0.99 & Alkane \\
\hline & Pentadecanal & 21.598 & 0.65 & Aldehyde \\
\hline & Oxirane, hexadecyl & 23.201 & 2.03 & Alkane \\
\hline & Vitamin E & 26.682 & 0.27 & Acid \\
\hline & 9,19- Cyclolanoston-3-ol, 24-methylene-(3.beta.) & 30.399 & 13.40 & Alkene \\
\hline \multirow{14}{*}{ Methanol } & Phosponic acid, (p-hydroxyphenyl) & 12.5 & 5.15 & Acid \\
\hline & Levoglucoseenone & 13.309 & 0.59 & Ketone \\
\hline & 2-furancarboxaldehyde, 5-(hydroxymethyl) & 16.443 & 1.2 & Aldehyde \\
\hline & 1,2-benzenediol & 17.008 & 0.72 & Alcohol \\
\hline & Hydrogen chloride & 17.491 & 0.47 & - \\
\hline & Phenol, 3,4-dimethoxy & 17.913 & 0.69 & Acid \\
\hline & Phenol,2-propyl & 18.017 & 3.12 & Acid \\
\hline & 1,4-benzenediol,2-methoxy & 18.777 & 0.65 & Alcohol \\
\hline & Benzaldehyde,4-hydroxy & 18.975 & 0.33 & Aldehyde \\
\hline & Phenol,3,4,5,-trimethoxy & 19.56 & 1.3 & Acid \\
\hline & Peroxypropione & 19.724 & 0.57 & Ketone \\
\hline & 2-propenal, 3-(4-hydroxy-3-methoxy phenyl) & 20.751 & 0.43 & Aldehyde \\
\hline & 3-hydroxy-4-methoxybenzoic acid & 20.986 & 1.95 & Acid \\
\hline & Benzoic acid, 4-hydroxy & 24.307 & 0.41 & Acid \\
\hline
\end{tabular}


ANTIOXIDANT ACTIVITIES FERRIC REDUCING ANTIOXIDANT POWER AND TOTAL ANTIOXIDANT CAPACITY ASSAYS

Three extracts of A. kemando were tested using iron reducing antioxidant power (FRAP) and antioxidant capacity assay (TAOC) (Table 4). The methanol extract exhibited the most promising activity with the highest FRAP and TAOC values while the chloroform extract displayed moderate activity. Unfortunately, hexane extract displayed weak activity with the lowest FRAP and TAOC values.

TABLE 4. The reduction power on $\mathrm{Fe}^{3+}$ complex (FRAP) and total antioxidant capacity (TAOC) of $A$. kemando extracts

\begin{tabular}{lcc}
\hline \multicolumn{1}{c}{ Plant extracts } & FRAP $(\mu \mathrm{mol} / \mathrm{g})$ & TAOC $(\mathrm{mg} / \mathrm{g})$ \\
\hline Hexane & $17.39 \pm 0.01$ & $112.32 \pm 0.01$ \\
Chloroform & $1328.11 \pm 0.04$ & $126.75 \pm 0.05$ \\
Methanol & $3382.00 \pm 0.4$ & $222.61 \pm 0.04$ \\
Ascorbic acid & $413.33 \pm 0.1$ & $1101.48 \pm 0.02$ \\
\hline
\end{tabular}

All values represented means \pm SD of three replicates. All samples were significantly different from ascorbic acid with $\mathrm{p}$ value $(\mathrm{p}<0.05)$

\section{SCAVENGING ACTIVITIES FOR DPPH AND ABTS FREE} RADICALS

The free radical scavenging activities test as shown in Table 5 shows that the methanol and chloroform extracts were able to scavenge $50 \%$ of DPPH radicals at 699.2 $\pm 0.01 \mu \mathrm{g} / \mathrm{mL}$ and $618 \pm 0.04 \mu \mathrm{g} / \mathrm{mL}$, respectively. In addition, $\mathrm{MeOH}$ extract at $262.21 \pm 0.02 \mu \mathrm{g} / \mathrm{mL}$ and $\mathrm{CHCl}_{3}$ extract at $898.01 \pm 0.01 \mu \mathrm{g} / \mathrm{mL}$ were able to scavenge $50 \%$ of ABTS radicals. Nevertheless, hexane extract did not show any inhibition towards these radicals.

TABLE 5. The $\mathrm{IC}_{50}$ values of DPPH and ABTS (free radical) inhibition of $A$. kemando plant extracts

\begin{tabular}{lcc}
\hline \multicolumn{1}{c}{ Crude extracts } & DPPH $(\mu \mathrm{g} / \mathrm{mL})$ & ABTS $(\mu \mathrm{g} / \mathrm{mL})$ \\
\hline Hexane & $>1000$ & $>1000$ \\
Chloroform & $618 \pm 0.04$ & $898.01 \pm 0.01$ \\
Methanol & $699.2 \pm 0.01$ & $262.21 \pm 0.02$ \\
Ascorbic acid & $39 \pm 0.6$ & $119.55 \pm 0.4$ \\
\hline
\end{tabular}

All values represented means \pm SD of three replicates. All samples were significantly different from ascorbic acid with $p$ value $(p<0.05)$

\section{B-CAROTENE-LINOLEIC ACID SYSTEM AND OXYGEN RADICAL ABSORBANCE CAPACITY ASSAY}

Kinetic study was done to determine the ability of $A$. kemando to prolong the antioxidant effect. Methanol extract showed the highest value in inhibition of beta- carotene decolourisation as shown in Table 6. This antioxidant activity was followed by chloroform and hexane extracts in decreasing order. Furthermore, all the crude extracts were tested for their ability to counteract the peroxy radical and inhibit probe fluorescence 
decolourisation as presented in Table 6 and Figure 2. In the present study, methanol and chloroform extracts displayed higher while the hexane extract showed lower antioxidant activities compared to the control, ascorbic acid.

TABLE 6. Effect of A. kemando extracts on beta-carotene bleaching (BC) and oxygen radical absorbance capacity (ORAC)

\begin{tabular}{lcc}
\hline \multicolumn{1}{c}{ Crude extracts } & BC (AA $\%)$ & ORAC $(\mu \mathrm{mol} / \mathrm{kg})$ \\
\hline Hexane & $36.66 \pm 0.01$ & $64690 \pm 3.2$ \\
Chloroform & $47.15 \pm 0.01$ & $100760 \pm 1.4$ \\
Methanol & $86.96 \pm 0.01$ & $13110 \pm 1.2$ \\
BHT & $50.28 \pm 0.7$ & - \\
Trolox & $88.31 \pm 0.9$ & - \\
Ascorbic acid & - & $84500 \pm 2.1$ \\
Quercetin & - & $72960 \pm 0.9$ \\
\hline
\end{tabular}

All values represented means \pm SD of three replicates

All samples were significantly different from BHT in BC result with $\mathrm{p}$ value $(\mathrm{p}<0.05)$

All samples were significantly different from ascorbic acid in ORAC with $\mathrm{p}$ value $(\mathrm{p}<0.05)$

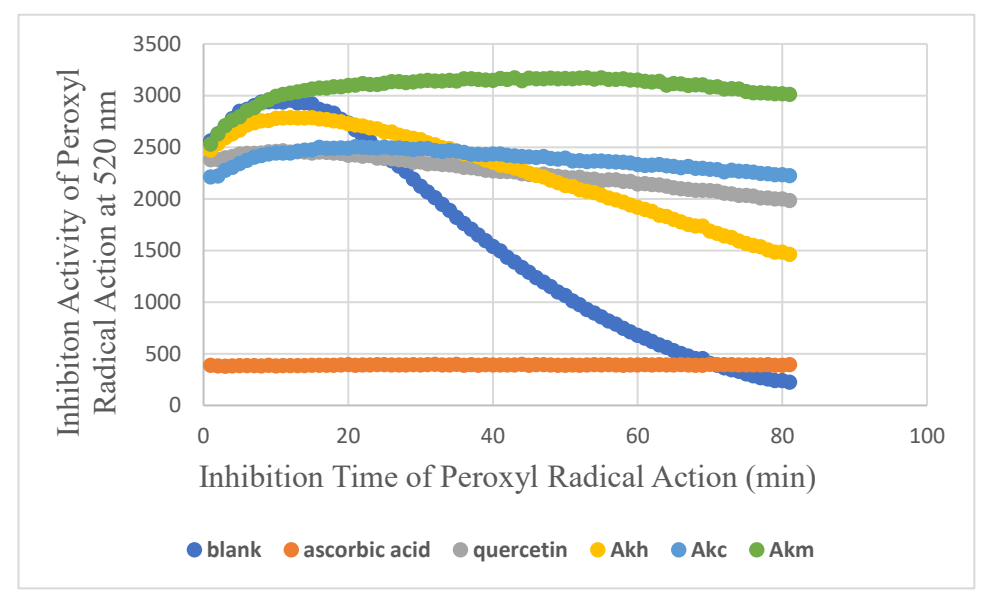

FIGURE 2. Florescence decay curve during ORAC assay in the presence of $A$. kemando extracts

\section{ANTIOXIDANT CYTOPROTECTIVE ASSAY}

Cell based antioxidant activity was carried out to determine the ability of $A$. kemando extracts to protect normal cell against cumene hydroperoxide. Cumene hydroperoxide at $94.4 \mu \mathrm{g} / \mathrm{mL}$ or $620 \mu \mathrm{M}$ was introduced to T1074 cells to provide a radical environment. According to the data in Table 7, methanol extract showed cytoprotective effect against the free radical at the lowest 
effective concentration $\left(\mathrm{EC}_{50}\right)$ value compared to the positive control (ascorbic acid). The chloroform extract showed moderate activity by inhibition while no activity was recorded for the hexane extract.

The cell count parameter was obtained using the same $\mathrm{EC}_{50}$. Figure 3 shows cell count based on the viability of cells that remained and were stained by Hoechst 33342 dye. Ascorbic acid showed the highest viable cell count (935 cells) after being exposed to the radical environment, followed by methanol (851 cells) and chloroform (437 cells) while negative control had 333 cells.

Figure 4 shows nuclei stained by Hoechst dye in different samples. Chloroform sample showed the most stained nuclei, followed by ascorbic acid, methanol and control. These results corresponded with Figure 5 as effective antioxidant would protect the whole cell structure including nucleus. In Figure 5, the morphological changes of 1074 cells were noticeable at different sample conditions using AOPI staining method. The negative control flask which consisted of cumene hydroperoxide without antioxidant showed higher number of late apoptotic cells (LA) compared to viable cells (VI). This contradicted with the chloroform extract that displayed higher VI than LA even at $64.78 \mu \mathrm{g} / \mathrm{mL}$. However, the methanol and ascorbic acid flasks showed the presence of VI and LA in equal number. This might be due to the antioxidant activity in the chloroform extract that protected the living cells from free radicals.

TABLE 7. The $\mathrm{EC}_{50}$ of $A$. kemando extracts against free radical in $\mathrm{T} 1074$ cell line after $1 \mathrm{~h}$ incubation

\begin{tabular}{|c|c|}
\hline Plant extracts & $\mathrm{EC}_{50}(\mu \mathrm{g} / \mathrm{mL})$ \\
\hline Hexane & NA \\
\hline Chloroform & $64.78 \pm 0.12$ \\
\hline Methanol & $21.48 \pm 0.27$ \\
\hline Ascorbic acid & $24.04 \pm 0.05$ \\
\hline Quercetin & $13.15 \pm 0.22$ \\
\hline
\end{tabular}

All values represented means \pm SD of three replicates. All samples were significantly different from ascorbic acid with $p$ value $(p<0.05)$

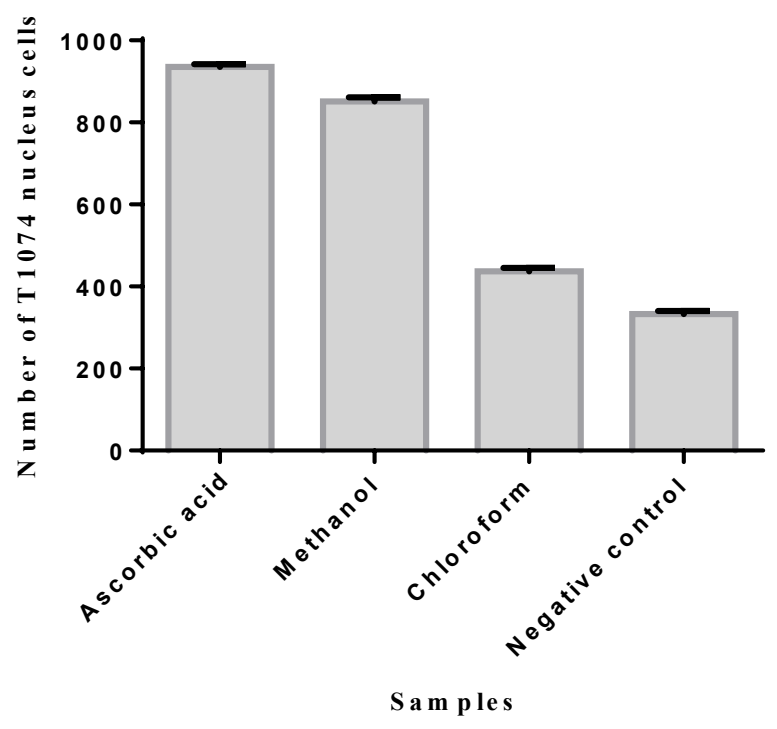

All values represented means \pm SD of three replicates. All samples were significantly different from control with $\mathrm{p}$ value $(\mathrm{p}<0.05)$

FIGURE 3. Cell count parameter using Hoechst dye staining in cytoprotective assay 

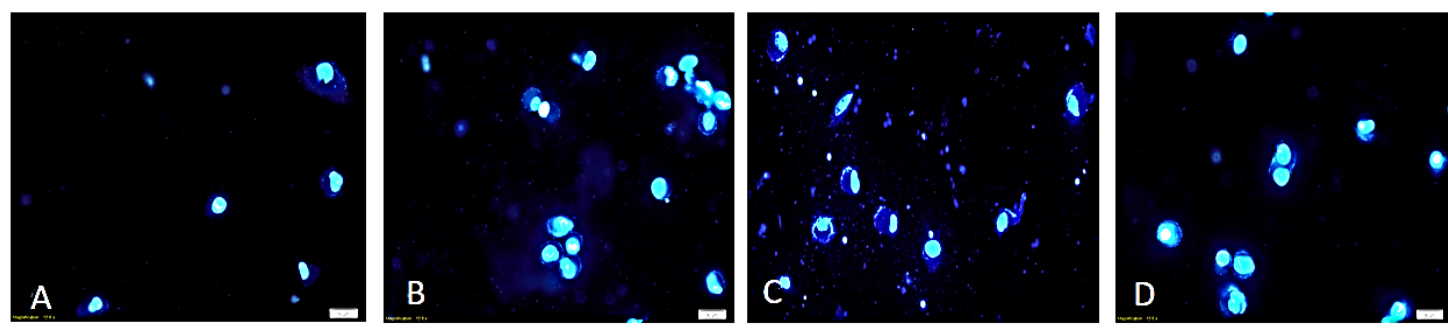

FIGURE 4. Fluorescence images of T1074 cells stained with Hoechst 33342 dye after 1 hour treatment. A. Negative control (untreated T1074 cells) has the lowest number of stained nuclei. B. T1074 cells after treatment with chloroform extract. C. T1074 cells treated with methanol extract. D. T1074 cells treated with ascorbic acid (magnification $40 \times$ )
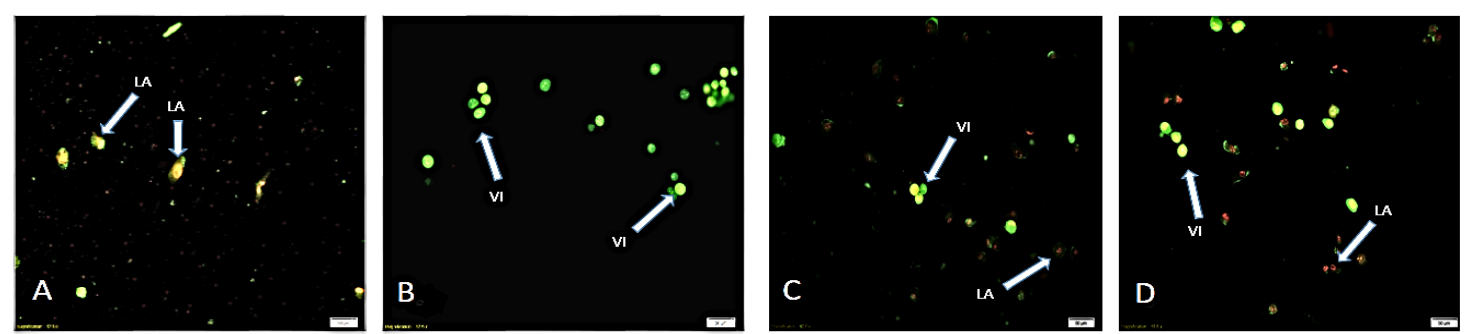

FIGURE 5. Fluorescence images of T1074 cells stained with Acridine Orange and Propidium Iodide double-stained after $1 \mathrm{~h}$ treatment. A. Negative control (untreated T1074 cells) has the highest number of morphological cell changes compared to the others. B. No morphological changes spotted in cells treated with chloroform extract. C. More unhealthy cells were shown in methanol extract treated cell. D. The healthy and unhealthy cells were spotted in the ascorbic acid treated cells. VI: viable cells, LA: late apoptosis (magnification $40 \times$ )

\section{CYTOTOXICITY ANALYSIS USING THE MTT ASSAY}

The cytotoxic effect of the $A$. kemando extracts on various cell lines was assessed using the MTT assay. Table 8 shows the cytotoxic effects of $A$. kemando extracts on different cell lines, while Table 9 shows the cytotoxic effects on ovarian cancer and normal cell lines after exposure for 24,48 and $72 \mathrm{~h}$. None of the samples showed cytotoxic effects except for the chloroform extract in CAOV-3 cells. The chloroform extract had higher $\mathrm{IC}_{50}$ value for these cells, compared with paclitaxel, a known standard drug that was used as the control in this assay. None of the samples displayed toxicity using the normal ovarian cell line, T1074.

TABLE 8. Cytotoxic effects of $A$. kemando extracts on a panel of cell lines

\begin{tabular}{lccccc}
\hline \multicolumn{2}{c}{$\begin{array}{c}\text { Plant extracts } \\
\text { MCF-7 }\end{array}$} & & \multicolumn{3}{c}{$\mathrm{IC}_{50}(\mu \mathrm{g} / \mathrm{mL})$} \\
\cline { 3 - 6 } Artocarpus kemando & Hexane & $>30$ & $>30$ & $>30$ & $>30$ \\
& Chloroform & $>30$ & $27.91 \pm 0.03$ & $>30$ & $>30$ \\
& Methanol & $15.8 \pm 0.17$ & $>30$ & $>30$ & $>30$ \\
\multirow{2}{*}{ Positive control } & Paclitaxel & $11.0 \pm 0.5$ & $9.76 \pm 0.3$ & - & - \\
& Vinblastine & - & - & $12.5 \pm 1.4$ & - \\
\hline
\end{tabular}

All values represented means $\pm \mathrm{SD}$ of three replicates

All samples were significantly different from positive control with $\mathrm{p}$ value $(\mathrm{p}<0.05)$ 
TABLE 9. The $\mathrm{IC}_{50}$ values of CAOV-3 cell treated with $A$. kemando extracts after different incubation periods using MTT assay

\begin{tabular}{lccc}
\hline \multirow{2}{*}{ Plants extracts } & & $\mathrm{IC}_{50}(\mu \mathrm{g} / \mathrm{mL})$ & \\
\cline { 2 - 4 } & $24 \mathrm{~h}$ & $48 \mathrm{~h}$ & $>30$ \\
\hline Hexane & $>30$ & $>30$ & $9.0 \pm 0.04$ \\
Chloroform & $27.9 \pm 0.03$ & $24.1 \pm 0.02$ & $>30$ \\
Methanol & $>30$ & $>30$ & - \\
Paclitaxel & $9.76 \pm 0.3$ & - & - \\
\hline
\end{tabular}

All values represented means $\pm \mathrm{SD}$ of three replicates

All samples were significantly different from positive control with $\mathrm{p}$ value $(\mathrm{p}<0.05)$

\section{MORPHOLOGICAL AND QUANTITATIVE ANALYSES OF \\ CAOV-3 CELLS AFTER TREATMENT WITH A. kemando CHLOROFORM EXTRACT AS ASSESSED BY FLUORESCENCE MICROSCOPY}

The chloroform extract was selected for morphological study at 24, 48 and $72 \mathrm{~h}$ of incubations. Figure 6 shows the untreated and treated cells stained with AOPI and observed under the fluorescence microscope. The untreated cells showed more cells with round shape and green intact nuclei. However, in the other treated culture flasks, CAOV3 cells started to undergo some morphological alterations even at $24 \mathrm{~h}$ treatment. The cell membrane started blebbing and fragmented DNA was obviously spotted by bright green fluorescence dots as shown in image B, Figure 6. The effect of the $\mathrm{CHCl}_{3}$ extract at $\mathrm{IC}_{50}$ dose against CAOV-3 cells was quantified (Figure 7) and exhibited a decrease in the number of viable cells and increase in the apoptotic cells as the incubation period increased.

In the control flask, higher number of viable cells was found compared to the cells having the blebbing structure. However, once the cells were treated with the crude extracts, the cells started to appear with several morphological changes such as chromatin condensation followed by blebbing, and apoptotic bodies were also observed (Figure 6(b)). The longer the exposure to the crude extract, the more changes occurred especially in cell blebbing which was observed at high concentration after $48 \mathrm{~h}$ of treatment. The number of apoptotic bodies increased after $72 \mathrm{~h}$ exposure of the cells to the chloroform crude extract with the least number of viable cells. The morphological changes showed in three different periods of exposure displayed changes in morphology towards the apoptotic response.
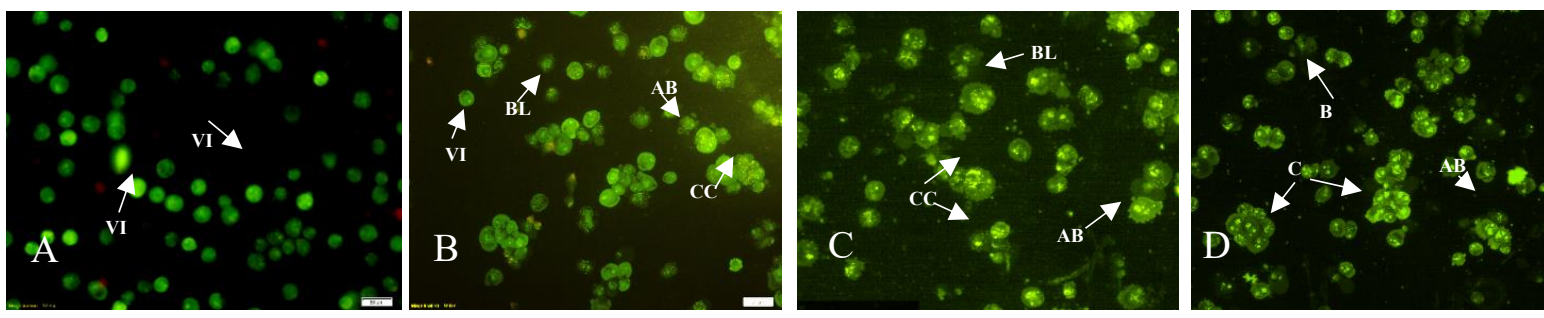

FIGURE 6. Fluorescence micrographs of Acridine Orange and Propidium Iodide double-stained on treated and untreated CAOV-3 cells. CAOV-3 cells were treated with chloroform extract of $A$. kemando at $\mathrm{IC}_{50}$ concentration in time-dependent manner: (a) untreated cells without any morphology changes either apoptosis or necrosis, (b) green dots of condensed chromatins clearly appeared along with viable cells after treatment for $24 \mathrm{~h}$ with crude extract,

(c) More membrane cell blebbings were seen in the cells as well as formation of apoptotic bodies and chromatin condensation after treatment for $48 \mathrm{~h}$, and (d) cells treated on the last day of incubation period ( $72 \mathrm{~h}$ ) showed most of the cells were unhealthy and many apoptotic bodies were formed. VI: viable cells, BL: blebbing of the cell membrane, CC: chromatin condensation, $\mathrm{AB}$ : apoptotic bodies (magnification $40 \times$ ) 


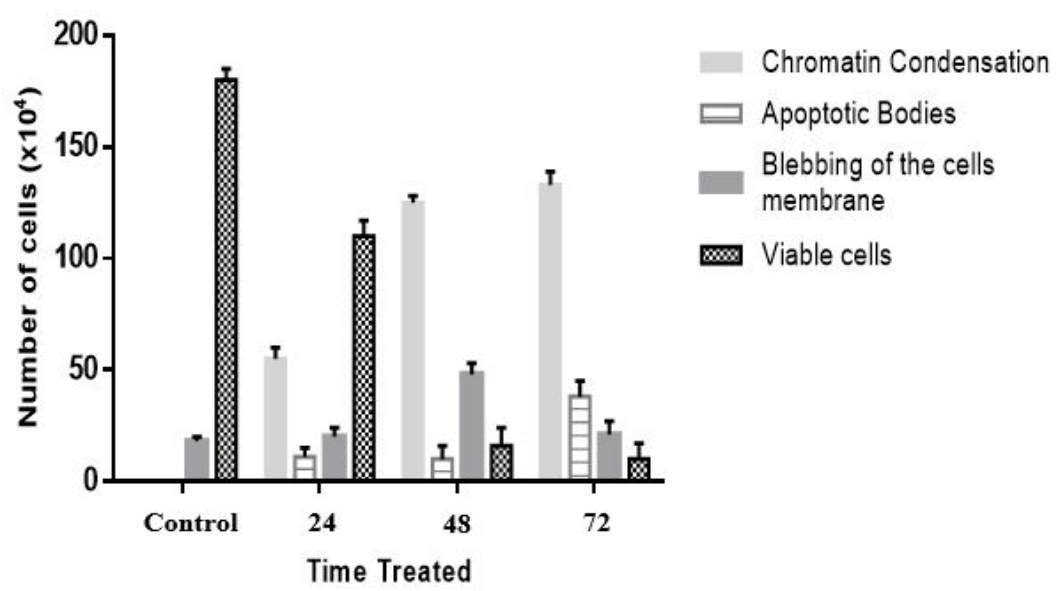

All values represented means \pm SD of three replicates. All samples were significantly different from control with $\mathrm{p}$ value $(\mathrm{p}<0.05)$

FIGURE 7. Quantitative analysis of untreated and treated CAOV-3 cells with chloroform extract of $A$. kemando at $\mathrm{IC}_{50}$ dose at three different time points $(24,48$, and $72 \mathrm{~h})$. Upon treatment with the $\mathrm{CHCl}_{3}$ extract against CAOV-3 cells at each time point, the number of viable cells decreased, while the cells formed into apoptotic bodies and chromatin condensations increased

\section{DISCUSSION}

Antioxidants play an important role in preventing oxidative damage. They neutralise and break the free radical chain reactions, thus controlling disease initiated by oxidative stress. However, certain antioxidant such as BHT has been questionable due to their potential health risks and suspected to cause liver damage and carcinogenesis (Maeura et al. 1984). Hence, stronger restrictions should be placed on their application and now there is a trend to replace them with naturally occurring antioxidants especially from plants. Plant species have been intensely investigated in the search for novel antioxidants (David et al. 2007; Harish \& Shivanandappa 2006; Wong et al. 2006). According to Kannan et al. (2010), to minimise the negative side effects, natural sources should be investigated extensively to find alternative antioxidants.

Hence in the present study, A. kemando was chosen. Previous studies on the plant extracts have exhibited notable DPPH free radical scavenging activity and cytotoxicity against oral epidermoid carcinoma, HL-60 and MCF-7 cancer cell lines (Ee et al. 2011; Seo et al. 2003; Teo et al. 2012). However, these findings were not for the whole extracts but based on the individual and targeted compounds present in the plant from previous study such as artonins $\mathrm{E}$ and $\mathrm{O}$, artobiloxanthone, cycloartobiloxanthone, artomandin, artonol B, artoindonesianin $\mathrm{C}$, artochamin $\mathrm{A}$, artosimmin and $\beta$-sitosterol. Studies on the bioactivity of $A$. kemando were very limited, especially concerning its antioxidant activity. Thus, this study has been carried out to investigate the antioxidant capacity of $A$. kemando and its underlying mechanisms. There are a number of different antioxidant mechanisms involved in rendering biological effects (Shahidi \& Ho 2007), including toxicity to cancer cells. However, this study did not carry out in vivo model which may be the limitation of the research. It only involved controlled environment and did not resemble the whole body system which is more complex and involves many factors.

A series of three different solvents with increasing polarity (hexane, chloroform, and methanol) were used to make extracts from the bark of A. kemando. The yield percentage of the different stem bark extracts from three $A$. kemando were presented in Table 1. Hexane is a non-polar solvent which is used to defat and extract lipophilic constituents. Hydrocarbons, waxes, squalene, triglycerides, $\alpha$-carotene, $\alpha$-sitosterol and $\alpha$-tocopherol were suspected to be extracted in the hexane extract (Tabera et al. 2004). In this study, chloroform was used as a semi-polar solvent to extract semi polar compounds. 
Finally, the plant was extracted using methanol to extract more polar compounds such as phenolics, flavonoids, polyphenols, proanthocyanidins, glycosides, and saponins (Naczk \& Shahidi 2004). Thus, this information may lead us to predict the result of antioxidant capacity in the respective extracts. Methanol extract contained more active compounds with antioxidant activity compared to others.

The present study showed that the TPC values were significantly higher than TFC in all extracts. This was due to the presence of other phenolic compounds in the plant that were not classified as flavonoids. According to Singleton and Rossi (1965), the Folin-Ciocalteu reagent used in the TPC reacted with all phenolic compounds, including both flavonoids and other phenolics, turning the yellow acidic solution to an intense blue colour. This explained why the TPC values were higher than TFC. The methanol extract of $A$. kemando bark exhibited the highest values for TPC and TFC as shown in Table 2, indicating that it contained the most phenolic compounds among the extracts. These findings were supported by the GC-MS result.

GC-MS analysis was also conducted to determine the chemical profiles of the A. kemando extracts. Identification of the phytochemical constituents present in each extract was established by comparing their retention times, peak areas and molecular weights to the similarity index in the NIST 08S library (Table 3 ). The long chain hydrocarbon alkenes, fatty acids and alcohols were detected in the crude chloroform extract of $A$. kemando. The high value for TPC (Table 2) was due to the presence of aromatic carboxylic acids such as benzoic acid in the extract. In the methanol extract, acid derivatives were identified in large quantities, for example 1,2-benzenediol, phenol, 3,4-dimethoxy, 2-propylphenol, 1,4-benzenediol, 3-hydroxy-4-methoxybenzoic acid and benzoic acid.

Further studies were carried out on the A. kemando extracts where the samples were tested for their antioxidant activities using the FRAP and TAOC assays (Table 4). The FRAP assay is an electron transfer-based method which collectively quantifies all electron-donating reductants present in a sample, thus measuring antioxidant capacity directly (Abu Bakar et al. 2009). In the FRAP assays, the methanol extract showed the highest FRAP value followed by the chloroform and hexane extracts. This was due to the large quantities of phenolic compounds (Table 3) in this extract resulting in the reduction of the FeTPTZ complex to form the intensely blue coloured ferrous solution which has also been identified as an antioxidant.
The moderate activity exhibited by the chloroform extract was likely due to the aromatic carboxylic acids present in the extract.

The total antioxidant activities (TAOC) was evaluated using a non-enzymatic antioxidant defense system known as the phosphomolybdenum technique. Table 4 shows that the methanol extract was capable of reducing molybdenum VI $\left(\mathrm{MO}^{6+}\right)$ to green phosphate molybdenum $\mathrm{V}$ more than other extracts indicating the presence of antioxidant activity in the extract. This supported the higher levels of phenolic compounds found in the methanol extract compared to the other extracts (Table 3).

The FRAP and TAOC assays (Table 4) were used to measure the ability of the extracts to reduce targeted substrates such as $\mathrm{Fe}^{3+}$ and molybdenum V. In these assays, oxidants or free radicals were not applied, hence the antioxidant activity may not match the reducing ability (Cao \& Prior 1998). Thus, further estimates of antioxidant capacity were made, involving the inactivation of free radical containing substances such as DPPH and ABTS. A. kemando extracts showed their ability to scavenge the DPPH and ABTS free radicals (Table 5). The chloroform extract exhibited a moderate scavenging activity for DPPH and a slightly weaker activity for ABTS. Meanwhile, the methanol extract exhibited a promising activity against ABTS but not towards DPPH. This unique situation might be due to the different compounds present in the extracts. DPPH can be used to measure the lipophilic antioxidants and the increased activity exhibited by the chloroform extract could be due to its lipophilic compounds present compared to the methanol extract (Table 3). Molyneux (2004) recorded the different compounds which are active in DPPH inhibition, such as polyhydroxy aromatics (hydroquinone and pyrogallol), aromatic amines (e.g. p-phenylsene diamine and $\mathrm{p}$-aminophenol), glutathione and vitamin $\mathrm{E}$, while noting that simple sugars (glucose), monohydric phenols (tyrosine), pyrimidines, and purines that are also present are not active in this assay. In the ABTS assay, the methanol extract exhibited a lower $\mathrm{IC}_{50}$ value compared to DPPH due to the ability of ABTS to dissolve in water and organic solvents, allowing it to quantify the compounds present in the extract. ABTS radicals are more reactive than DPPH radicals (Lü et al. 2010) and have the ability to show the total scavenging activity of both lipophilic and hydrophilic antioxidants. However, some compounds or antioxidants are not stable beyond a certain time. In order to compare with other principle of antioxidant reaction, 
hydrogen atom transfer assay and kinetics study were performed.

The $\beta$-carotene bleaching assay (BC) and the oxygen radical absorbance capacity (ORAC) were used for the kinetic study. Linoleic acid is a source of radicals, generating hydroperoxide when incubated at high temperatures $\left(50^{\circ} \mathrm{C}\right)$ (Kassim et al. 2013). However, the addition of antioxidants could inhibit the decolourisation of carotenoids that occur in oxidative environments. The $\mathrm{BC}$ yellow colour can persist, or its decolourisation can be slowed down by the presence of antioxidant activities as reported by Kassim et al. (2013) and Zubia et al. (2009). Table 6 shows the $\beta$-carotene bleaching assay and oxygen radical absorbance capacity of the A. kemando extracts. The methanol extract exhibited the highest potential for preserving the colour of $\mathrm{BC}$ and fluorescence. The methanol extract was able to preserve the fluorescence colour to a similar extent as ascorbic acid, in contrast with the blank and other extracts (Figure 2). This finding suggested that the methanol extract was able to inhibit peroxyl radicals that destroyed the colour. Table 3 shows the presence of phenolic compounds in the methanol extract which resulted in the ability of this extract to maintain antioxidant activity depending on the temperature and time parameters. Nevertheless, the chloroform extract also showed potential activity although to a lesser extent than the methanol extract.

The ORAC and BC assays exploit a classic hydrogen atom transfer mechanism (Apak et al. 2016). $\beta$-carotene is used to measure kinetic parameters of lipophilic antioxidants while ORAC is used to measure the hydrophilic antioxidants. Pinchuk et al. (2012) stated that kinetic measurements are required to determine the capacity and potency of an antioxidant, because the antioxidant cannot be characterised from the effect of an antioxidant against oxidation concentration at a given time point only.

Potent antioxidants which are effective in a controlled environment must also be tested on cells. Thus, the subsequent series of experiments in this study assessed the cytoprotective effects of antioxidants in normal cells. There were many studies involving antioxidants but there was no report on the cytoprotective effects of $A$. kemando. Protective effects cannot be determined simply by assessing the chemical antioxidant activity, it should be tested in living systems such as human cells. The cytoprotective effects of the extracts were analysed by observing cell viability and morphology after exposure to free radical inducers such as cumene hydroperoxide. Most studies reported cell viability in experiments concerning cytoprotective effects, but not on the cell morphology as reported by Tomosaka et al. (2008) on MCF-7 cell. In Table 7 , the chloroform and methanol extracts clearly displayed cytoprotection on T1074 cells whereby the methanol extract itself exhibited the lowest $\mathrm{EC}_{50}$ value which is comparable to the positive control (ascorbic acid). Ascorbic acid may not perform well in the cellular environment as it easily degrades in storage and over time (Sapei \& Hwa 2014). However, the number of viable cells stained in the ascorbic acid sample was slightly higher than in the methanol extract sample, followed by the chloroform and hexane extracts and the negative control (Figure 3). In San Tang (2014), palmitic acid or hexadecanoic acid was used as an inducer of apoptosis and cell death. The compound was identified in both hexane and chloroform extracts which cause cell death other than the presence of cumene peroxide.

However, in Figure 4, the chloroform extract showed more viable stained nuclei compared to methanol extract and ascorbic acid. This led to another staining method (AO/ PI staining) to reconfirm the result in cell morphological changes. Interestingly, using AO and PI double-staining, as shown in Figure 5, even the chloroform extract showed a moderate $\mathrm{EC}_{50}$ and fewer number of nuclei stained by Hoechst dye, the cells treated by chloroform did not undergo morphological changes compared to the other samples. Late apoptotic cells were observed in methanol extract and ascorbic acid treated samples but not in the chloroform treated flask. In the data shown, the methanol extract had the highest antioxidant activity in most of the assays, while the chloroform extract showed moderate activity. However, the chloroform extract showed protective effect in cellular level even though it only has moderate activity in chemical based antioxidant.

Previous researcher used MTT and manual cell counting to monitor the viable cell as reported in $\mathrm{Xu}$ et al. (2018) while Mittal et al. (2018) used cell morphological changes parameter in their cytoprotective study. Both methods are important as they give different aspects on how the antioxidant works at cellular level thus had been included in this study. Cell morphological changes happen when the cells are exposed to oxidant, and lead to cells death. In this study, the chloroform extract was capable of minimising the morphological changes of the cells even in the presence of cumene hydoperoxide. This showed that the chloroform extract has cytoprotective potential even though it has moderate antioxidant activity.

On the other hand, the methanol extract contained a high concentration of free radical scavengers, but too much of it will turn into pro-oxidant action which may 
cause harm to the cell (Incani et al. 2016). Another finding found by Pinteus et al. (2017), showed similar situation whereby the methanolic extract of Sargassum muticum, which has higher antioxidant capability, seemed to produce a pro-oxidant effect instead of protecting the cells. Videla (2010) reported that a mild pro-oxidant was needed, for example thyroid hormone, which activated the production of proteins and offered protection to liver cells. Thus, some degree of oxidative stress induced by phenolic compounds was required, but the phenolics should only be at a moderate concentration such as in the chloroform extracts. Although there is no limitation in consuming phenols through our diet, however, according to Singleton and Rossi (1965), consuming $500 \mathrm{mg}$ of polyphenols through diet will result in $50 \mu \mathrm{M}$ increase of polyphenols concentration in plasma. Scalbert and Williamson (2000) reported that not more than $1000 \mathrm{mg}$ of polyphenols had been used to test on polyphenols bioavailability, thus this finding supported that the TPC values of all extracts were still within the bioavailability range in treating the cell. In this study, not all extracts with high antioxidant levels produced beneficial activities in the cellular environment. Pro-oxidant features in the antioxidant extracts may cause cytotoxic effects on targeted cells particularly in previously studied tumour cell lines. The subsequent experiments were thus focused on antitumour cell assay.

The MTT assay was performed to determine the ability of the extracts to kill cancer cells. Shier et al. (1991) mentioned that, according to United States National Cancer Institute guideline, any compounds that exhibit IC50 value of more than $30 \mu \mathrm{g} / \mathrm{mL}$ are considered as not potentially cytotoxic, thus, this is the reference for us to start the initial concentration at $30 \mu \mathrm{g} / \mathrm{mL}$ in order to find the most potential extract exhibit toxicity to cancer cell. Focusing on ovarian cell line, the samples did not give positive result except for the chloroform extract. Surprisingly, the methanol extract, which was a good antioxidant, showed no cytotoxic activity on the ovarian cancer cell line and even enhanced the proliferation of cancer cells. This may be due to pro-oxidant activity in the extract. Murrell et al. (1990) stated that pro-oxidants can both stimulate or inhibit the proliferation process. However, in the case of the methanol extract, pro-oxidant mediated cell proliferation may have occurred, which triggered the activation of protein kinases in cellular function activation and cell proliferation (Richter 1993). However, the chloroform extract was able to inhibit the proliferation of ovarian cancer cells and this continued for 48 and $72 \mathrm{~h}$ at low concentration (Table 9). On the other hand, none of the samples from $A$. kemando had harmful effects on the normal ovarian cell line. This is in agreement with the protective effect found for the $A$. kemando extract in the cell protection assay.

According to Chan et al. (2006), the MTT assay only measures cell death via Krebs cycle activity in intact mitochondria, while the AO/PI method is essential to quantify cell death using morphological changes and plasma membrane integrity parameters. In programmed cell death, normal cells go through the apoptosis process. However, due to genetic changes in cancer cells, programmed cell death via apoptosis fails to function, and may lead to the development of cancer (Brown \& Attardi 2005). Induction of cell death through apoptosis is preferred compared to necrosis as it may induce inflammation and downstream reaction (Stoneman \& Bennett 2004). Figures 6 and 7 show the increase of chromatin condensation in cancer cells caused by $A$. kemando extracts exposure against time. Chromatin condensation is a result of the release of proapoptotic proteins into the cytosol, which originate from mitochondria during early apoptosis (Elmore 2007). According to Kawase et al. (2008), increased exposure time of cancer cells to drugs causes prominent apoptosis effects such as blebbing of plasma membranes, separated cell fragments that form non-nuclear packed organelles called apoptotic bodies.

\section{CONCLUSION}

In conclusion, the methanol extract of A. kemando exhibited promising antioxidant activities with significant result compared to other crude extracts in free radical scavenging, antioxidant capacity measurement, kinetics study and cell protective assay. Meanwhile, chloroform extract exhibited moderate antioxidant activity except in DPPH assay. The varieties of antioxidant observed in the $A$. kemando extracts were mainly due to the presence of several major compounds such as benzoic acid and phenol that can be found in each extract. Phenols and acids were identified in methanol which displayed the strongest reaction in oxidative study while carboxylic acid and alkenes were mostly found in the chloroform extract and showed mild antioxidant activity. This could provide a scientific evidence for ethnopharmacological treatment of oxidative stress related disease. However, in the CAOV-3 cancer cell, chloroform extract showed an interesting result by inhibiting cancer cells growth even though it has moderate activity in the oxidative study. It was also shown that the death of CAOV-3 cells were caused by apoptosis reaction and not due to other reactions such as necrosis. However, in this study, high antioxidant 
concentration displayed by methanol was able to show pro-oxidant exhibited in its CAOV-3 cells, thus did not inhibit but induced the cells growth. In this study, methanol extract was the perfect candidate as antioxidant extract compared to other extracts. However, chloroform extract was more suitable as antitumour candidate against CAOV3 cell line. This finding showed that even as moderate antioxidant, chloroform was able to generate cytotoxicity on specific cell cancer. Antioxidant drugs contribute to antitumour activity but only at certain concentration, as higher concentration of antioxidant may lead to prooxidant. As shown in methanol extract, high concentration of antioxidant led to pro-oxidant reaction which induced cells proliferation instead of inhibiting the CAOV-3 cells growth. To date, this is the first report on the oxygen radical absorbance and cytotoxicity capacities of $A$. kemando on CAOV-3 cancer cell.

\section{ACKNOWLEDGEMENTS}

This work was financed by the High Impact Research grant, UM-MOHE UM.C/625/1/HIR/MOHE/SC/09 and UMRG Grant, Flagship-RP00IC-13BIO.

\section{REFERENCES}

Abu Bakar, M.F., Mohamed, M., Rahmat, A. \& Fry, J. 2009. Phytochemicals and antioxidant activity of different parts of bambangan (Mangifera pajang) and tarap (Artocarpus odoratissimus). Food Chemistry 113: 479-483.

Altuntaş, G. \& Değer, Y. 2017. The effects of butylated hydroxyl toluene on the total antioxidant status/total oxidant stress and biochemical parameters in rats. World Journal of Pharmacy and Pharmaceutical Science 6: 199-210.

Apak, R., Özyürek, M., Güçlü, K. \& Çapanoğlu, E. 2016. Antioxidant activity/capacity measurement: Classification, physicochemical principles, mechanisms, and electron transfer (ET)-based assays. Journal of Agricultural and Food Chemistry 64: 997-1027.

Azwanida, N. 2015. A review on the extraction methods use in medicinal plants, principle, strength and limitation. Medicinal and Aromatic Plants 4(196): 2167-0412.

Benzie, I.F. \& Strain, J. 1996. The ferric reducing ability of plasma (FRAP) as a measure of "antioxidant power": The FRAP assay. Analytical Biochemistry 239: 70-76.

Beta, T., Naing, S.K., Nam, S., Mpofu, A. \& Therrien, M. 2007. Antioxidant activity in relationship to phenolic content of diverse food barley genotypes. In Antioxidant Measurement and Application, edited by Fereidoon, S. \& Chi, T.H. Washington: American Chemical Society. pp. 242-254.

Brown, J.M. \& Attardi, L.D. 2005. The role of apoptosis in cancer development and treatment response. Nature Reviews Cancer 5: 231-237.

Cao, G. \& Prior, R.L. 1998. Comparison of different analytical methods for assessing total antioxidant capacity of human serum. Clinical Chemistry 44: 1309-1315.
Chan, K., Rajab, N.F., Ishak, M., Ali, A., Yusoff, K., Din, L. \& Inayat-Hussain, S. 2006. Goniothalamin induces apoptosis in vascular smooth muscle cells. Chemico-Biological Interactions 159(2): 129-140.

Chang, C.C., Yang, M.H., Wen, H.M. \& Chern, J.C. 2002. Estimation of total flavonoid content in propolis by two complementary colorimetric methods. Journal of Food and Drug Analysis 10: 178-182.

Dávalos, A., Gómez-Cordovés, C. \& Bartolomé, B. 2004. Extending applicability of the oxygen radical absorbance capacity (ORAC- fluorescein) assay. Journal of Agricultural and Food Chemistry 52: 48-54.

David, J.P., Meira, M., David, J.M., Brandão, H.N., Branco, A., de Fátima Agra, M., Barbosa, M.R.V., de Queiroz, L.P. \& Giulietti, A.M. 2007. Radical scavenging, antioxidant and cytotoxic activity of Brazilian caatinga plants. Fitoterapia 78: 215-218.

Dudonné, S., Vitrac, X., Coutiere, P., Woillez, M. \& Mérillon, J.M. 2009. Comparative study of antioxidant properties and total phenolic content of 30 plant extracts of industrial interest using DPPH, ABTS, FRAP, SOD, and ORAC assays. Journal of Agricultural and Food Chemistry 57: 17681774.

Ee, G.C.L., Teo, S.H., Rahmani, M., Lim, C.K., Lim, Y.M. \& Go, R. 2011. Artomandin, a new xanthone from Artocarpus kemando (Moraceae). Natural Product Research 25: 9951003.

Elmore, S. 2007. Apoptosis: A review of programmed cell death. Toxicologic Pathology 35: 495-516.

Govindarajan, R., Rastogi, S., Vijayakumar, M., Shirwaikar, A., Rawat, A.K.S., Mehrotra, S. \& Pushpangadan, P. 2003. Studies on the antioxidant activities of Desmodium gangeticum. Biological and Pharmaceutical Bulletin 26: 1424-1427.

Harish, R. \& Shivanandappa, T. 2006. Antioxidant activity and hepatoprotective potential of Phyllanthus niruri. Food Chemistry 95: 180-185.

Hashim, N.M., Rahmani, M., Ee, G.C.L., Sukari, M.A., Yahayu, M., Amin, M.A.M., Ali, A.M. \& Go, R. 2012. Antioxidant, antimicrobial and tyrosinase inhibitory activities of xanthones isolated from Artocarpus obtusus FM Jarrett. Molecules 17: 6071-6082.

Hashim, N.M., Rahmani, M., Shamaun, S.S., Ee, G.C.L., Sukari, M.A., Ali, A.M. \& Go, R. 2011. Dipeptide and xanthones from Artocarpus kemando Miq. Journal of Medicinal Plant Research 5: 4224-4230.

Incani, A., Serra, G., Atzeri, A., Melis, M.P., Serreli, G., Bandino, G., Sedda, P., Campus, M., Tuberoso, C.I. \& Deiana, M. 2016. Extra virgin olive oil phenolic extracts counteract the prooxidant effect of dietary oxidized lipids in human intestinal cells. Food and Chemical Toxicology 90: 171-180.

Jagtap, U. \& Bapat, V. 2010. Artocarpus: A review of its traditional uses, phytochemistry and pharmacology. Journal of Ethnopharmacology 129: 142-166.

Jamil, S., Sirat, H.M., Jantan, I., Aimi, N. \& Kitajima, M. 2008. A new prenylated dihydrochalcone from the leaves of Artocarpus lowii. Journal of Natural Medicines 62: 321-324. 
Kannan, R.R.R., Arumugam, R. \& Anantharaman, P. 2010. In vitro antioxidant activities of ethanol extract from Enhalus acoroides (LF) royle. Asian Pacific Journal of Tropical Medicine 3: 898-901.

Kassim, N.K., Rahmani, M., Ismail, A., Sukari, M.A., Ee, G.C.L., Nasir, N.M. \& Awang, K. 2013. Antioxidant activity-guided separation of coumarins and lignan from Melicope glabra (Rutaceae). Food Chemistry 139: 87-92.

Kawase, T., Ichikawa, H., Ohta, T., Nozaki, N., Tashiro, F., Ohki, R. \& Taya, Y. 2008. p53 target gene AEN is a nuclear exonuclease required for p53-dependent apoptosis. Oncogene 27: 3797-3810.

Khan, M., Omoloso, A. \& Kihara, M. 2003. Antibacterial activity of Artocarpus heterophyllus. Fitoterapia 74: 501-505.

Lü, J.M., Lin, P.H., Yao, Q. \& Chen, C. 2010. Chemical and molecular mechanisms of antioxidants: Experimental approaches and model systems. Journal of Cellular and Molecular Medicine 14: 840-860

Maeura, Y., Weisburger, J.H. \& Williams, G.M. 1984. Dosedependent reduction of N-2-fluorenylacetamide-induced liver cancer and enhancement of bladder cancer in rats by butylated hydroxytoluene. Cancer Research 44: 1604-1610.

Matés, J.M., Pérez-Gómez, C. \& De Castro, I.N. 1999. Antioxidant enzymes and human diseases. Clinical Biochemistry 32: 595-603.

Mittal, A., Tandon, S., Singla, S.K. \& Tandon, C. 2018 Modulation of lithiatic injury to renal epithelial cells by aqueous extract of Terminalia arjuna. Journal of Herbal Medicine 13: 63-70.

Molyneux, P. 2004. The use of the stable free radical diphenylpicrylhydrazyl (DPPH) for estimating antioxidant activity. Songklanakarin Journal of Science and Technology 26: 211-219.

Mosmann, T. 1983. Rapid colorimetric assay for cellular growth and survival: Application to proliferation and cytotoxicity assays. Journal of Immunological Methods 65: 55-63.

Murrell, G.A., Francis, M.J. \& Bromley, L. 1990. Modulation of fibroblast proliferation by oxygen free radicals. Biochemical Journal 265: 659-665.

Naczk, M. \& Shahidi, F. 2004. Extraction and analysis of phenolics in food. Journal of Chromatography A 1054: 95-111.

Nair, V.D., Panneerselvam, R. \& Gopi, R. 2012. Studies on methanolic extract of Rauvolfia species from Southern Western Ghats of India - In vitro antioxidant properties, characterisation of nutrients and phytochemicals. Industrial Crops and Products 39: 17-25.

Oki, T., Masuda, M., Furuta, S., Nishiba, Y., Terahara, N. \& Suda, I. 2002. Involvement of anthocyanins and other phenolic compounds in radical-scavenging activity of purple-fleshed sweet potato cultivars. Journal of Food Science 67: 17521756.

Pinchuk, I., Shoval, H., Dotan, Y. \& Lichtenberg, D. 2012. Evaluation of antioxidants: Scope, limitations and relevance of assays. Chemistry and Physics of Lipids 165: 638-647.
Pinteus, S., Silva, J., Alves, C., Horta, A., Fino, N., Rodrigues, A.I., Mendes, S. \& Pedrosa, R. 2017. Cytoprotective effect of seaweeds with high antioxidant activity from the Peniche coast (Portugal). Food Chemistry 218: 591-599.

Richter, C. 1993. Pro-oxidants and mitochondrial $\mathrm{Ca}^{2+}$ : Their relationship to apoptosis and oncogenesis. FEBS Letters 325: 104-107.

San Tang, K. 2014. Protective effect of arachidonic acid and linoleic acid on 1-methyl-4-phenylpyridinium-induced toxicity in PC12 cells. Lipids in Health and Disease 13: 1.

Sapei, L. \& Hwa, L. 2014. Study on the kinetics of vitamin C degradation in fresh strawberry juices. Procedia Chemistry 9: 62-68.

Scalbert, A. \& Williamson, G. 2000. Dietary intake and bioavailability of polyphenols. The Journal of Nutrition 130: 2073S-2085S.

Seo, E.K., Lee, D., Shin, Y.G., Chai, H.B., Navarro, H.A., Kardono, L., Rahman, I., Cordell, G.A., Farnsworth, N.R. \& Pezzuto, J.M. 2003. Bioactive prenylated flavonoids from the stem bark of Artocarpus kemando. Archives of Pharmacal Research 26: 124-127.

Shahidi, F. \& Ho, C.T. 2007. Antioxidant Measurement and Applications. Washington: American Chemical Society. pp. 2-7.

Shier, W.T., Abbas, H. \& Mirocha, C. 1991. Toxicity of the mycotoxins fumonisins B 1 and B 2 and Alternaria alternata f. sp. lycopersici toxin (AAL) in cultured mammalian cells. Mycopathologia 116: 97-104.

Singleton, V. \& Rossi, J.A. 1965. Colorimetry of total phenolics with phosphomolybdic-phosphotungstic acid reagents. American Journal of Enology and Viticulture 16: 144-158.

Stoneman, V.E. \& Bennett, M.R. 2004. Role of apoptosis in atherosclerosis and its therapeutic implications. Clinical Science 107: 343-354.

Sun, L., Zhang, J., Lu, X., Zhang, L. \& Zhang, Y. 2011. Evaluation to the antioxidant activity of total flavonoids extract from persimmon (Diospyros kaki L.) leaves. Food and Chemical Toxicology 49: 2689-2696.

Tabera, J., Guinda, Á., Ruiz-Rodríguez, A., Señoráns, F.J., Ibáñez, E., Albi, T. \& Reglero, G. 2004. Countercurrent supercritical fluid extraction and fractionation of highadded-value compounds from a hexane extract of olive leaves. Journal of Agricultural and Food Chemistry 52: 4774-4779.

Teo, S., Go, R., Lim, C. \& Lim, Y. 2012. Free radical scavenging effect of Artocarpus kemando and Artocarpus odoratissimus: Structure-activity relationship of flavonoid derivatives. Asian Journal of Chemistry 24: 231.

Tomosaka, H., Chin, Y.W., Salim, A.A., Keller, W.J., Chai, H. \& Kinghorn, A.D. 2008. Antioxidant and cytoprotective compounds from Berberis vulgaris (barberry). Phytotherapy Research 22: 979-981.

Valko, M., Leibfritz, D., Moncol, J., Cronin, M.T., Mazur, M. \& Telser, J. 2007. Free radicals and antioxidants in normal physiological functions and human disease. The International Journal of Biochemistry \& Cell Biology 39: 44-84. 
Videla, L.A. 2010. Cytoprotective and suicidal signaling in oxidative stress. Biological Research 43: 363-369.

Wei, B.L., Weng, J.R., Chiu, P.H., Hung, C.F., Wang, J.P. \& Lin, C.N. 2005. Antiinflammatory flavonoids from Artocarpus heterophyllus and Artocarpus communis. Journal of Agricultural and Food Chemistry 53: 3867-3871.

Witschi, H., Malkinson, A.M. \& Thompson, J.A. 1989. Metabolism and pulmonary toxicity of butylated hydroxytoluene (BHT). Pharmacology \& Therapeutics 42: 89-113.

Wong, S.P., Leong, L.P. \& Koh, J.H.W. 2006. Antioxidant activities of aqueous extracts of selected plants. Food Chemistry 99: 775-783.

Xu, W., Saiki, S., Myojin, T., Liu, Y., Zhu, B., Murata, Y., Ashida, H., Tsunenaga, M. \& Nakamura, Y. 2018. Lycii fructus extract ameliorates hydrogen peroxide-induced cytotoxicity through indirect antioxidant action. Bioscience, Biotechnology, and Biochemistry 82(10): 1812-1820.

Zubia, M., Fabre, M.S., Kerjean, V., Le Lann, K., StigerPouvreau, V., Fauchon, M. \& Deslandes, E. 2009. Antioxidant and antitumoural activities of some Phaeophyta from Brittany coasts. Food Chemistry 116: 693-701.
Noor Shafifiyaz Mohd Yazid* \& Najihah Mohd Hashim Department of Pharmacy

Faculty of Medicine

University of Malaya

50603 Kuala Lumpur, Federal Territory

Malaysia

Hapipah Mohd Ali

Department of Chemistry

Faculty of Science

University of Malaya

50603 Kuala Lumpur, Federal Territory

Malaysia

Rusea Go

Department of Biology

Faculty of Science

Universiti Putra Malaysia

43400 UPM Serdang, Selangor Darul Ehsan

Malaysia

*Corresponding author; email: shafifiyaz63@gmail.com

Received: 20 September 2019

Accepted: 22 September 2020 